\title{
PENINGKATAN KEMAMPUAN GURU DALAM MENYUSUN RENCANA PELAKSANAAN PEMBELAJARAN (RPP) MELALUI WORKSHOP DI SMPN 1 KECAMATAN HARAU
}

\author{
Muhammad Yusuf Lubis
}

\author{
Kepala UPTD SMPN 1 Kecamatan Harau
} myusuflubis.sahara@gmail.com

\begin{abstract}
This research is a School Action Research (SAR). The aim of this research is to improve the teachers' ability to prepare lesson plans through a workshop at SMPN 1 Kecamatan Harau. The research subjects were 22 teachers. The research was carried out in Semester 1 of the 2018/2019 academic year which was carried out in 2 cycles. Data were collected using the RPP assessment format. From the research findings, it was found that the use of workshops in an effort to improve the ability of teachers to prepare the lesson plans at SMPN 1 Kecamatan Harau, Lima Puluh Kota District, is very good. This is proven by an increase in the ability of teachers in preparing lesson plans through workshops at SMPN 1 Harau District for the $2018 / 2019$ academic year from pre-cycle to cycle I of $10.12 \%$ and from cycle I to Cycle II of $14.07 \%$.

Keywords: Teachers' Ability, Lesson Plan, Workshop.
\end{abstract}

\begin{abstract}
ABSTRAK
Penelitian ini adalah Penelitian Tindakan Sekolah (PTS). PTS ini bertujuan untuk meningkatkan kemampuan guru menyusun RPP melalui Workshop di SMPN 1 Kecamatan Harau. Subyek penelitian adalah guru mata pelajaran sebanyak 22 orang. Penelitian dilaksanakan pada Semester 1 tahun pelajaran 2018/2019 yang dilaksanakan dalam 2 siklus. Data dikumpulkan dengan menggunakan format penilaian RPP. Dari temuan penelitian diperoleh bahwa penggunaan workshop dalam upaya meningkatkan kemampuan guru menyusun rencana pelaksanaan pembelajaran di SMPN 1 Kecamatan Harau Kabupaten Lima Puluh Kota, adalah baik sekali. Ini terbukti terjadi peningkatan kemampuan guru dalam menyusun RPP melalui workshop di SMPN 1 Kecamatan Harau Tahun Pelajaran 2018/2019 dari prasiklus ke siklus I sebesar 10,12\% dan dari siklus I ke Siklus II sebesar 14,07\%. Kata Kunci: Kemampuan Guru, RPP, Workshop.
\end{abstract}

\section{PENDAHULUAN}

Tugas pokok seorang guru berdasarkan Permennegpan (2009) Bab III pasal 6 diantaranya adalah merencanakan pembelajaran/bimbingan, melaksanakan pembelajaran/bimbingan yang bermutu, menilai dan mengevaluasi hasil pembelajaran/bimbingan, serta melaksanakan pembelajaran/perbaikan dan pengayaan; guru merupakan salah satu komponen pendidikan yang memiliki peranan penting dalam mencapai tujuan pendidikan. Sebab, guru yang berinteraksi langsung dengan peserta didik dalam proses belajar mengajar. Maka dari itu kualitas guru akan sangat mempengaruhi kualitas peserta didiknya.

Kompetensi yang berkaitan dengan pelaksanaan pembelajaran adalah kompetensi pedagogik, karena kompetensi pedagogik ini meliputi pemahaman terhadap peserta didik, perencanaan dan pelaksanaan pembelajaran, evaluasi hasil 
belajar, dan pengembangan peserta didik untuk mengaktualisasaikan berbagai potensi yang dimilikinya.

Kemampuan menyusun Rencana Pelaksanaan Pembelajaran bagi seorang guru sangat penting, karena dengan perencanaan yang baik, matang dan terarah dapat menentukan keberhasilan pembelajaran. Standar Proses, perencanaan proses pembelajaran meliputi Silabus dan Rencana Pelaksanaan Pembelajaran (RPP).

Selanjutnya dalam Peraturan Pemerintah No. 19 tahun 2005 tentang Standar Nasional Pendidikan pasal 20 dijelaskan bahwa proses pembelajaran meliputi silabus dan rencana pelaksanaan pembelajaran.

kompetensi yang harus dimiliki oleh tenaga guru antara lain kemampuan pedagogik, kepribadian, profesional dan sosial yang diperoleh melalui pendidikan profesi, keempat kompetensi tersebut terintegrasi dalam kinerja guru. Namun kenyataanya belum semua guru mampu menguasai keempat kompetensi tersebut, sehingga membuat kinerja guru kurang optimal dalam menjalankan tugasnya.

Kenyataan yang peneliti temukan di SMPN 1 Kecamatan Harau masih banyak guru yang memiliki kompetensi yang baik untuk menyusun rencana pelaksanaan pembelajaran secara lengkap dan sistematis. Kurangnya kemampuan guru tersebut bisa dilatarbelakangi oleh beberapa faktor, antara lain: (1) kurangnya pemahaman guru tentang pentingnya perananan perencanaan pembelajaran; (2) kurang optimalnya kepala sekolah dalam pelaksanaan kegiatan supervisi akademik membimbing dan membina guru dalam penyusunan rencana pelaksanaan pembelajaran.

Berdasarkan data hasil supervisi di SMPN 1 Kec. Harau Kabupaten Lima Puluh Kota, yang dilakukan peneliti terhadap guru mata pelajaran sebanyak 20 orang dokumen RPP pada semester I Tahun Pelajaran 2018/2019 diperoleh data kondisi awal bahwa RPP yang telah dibuat guru masih kurang benar, kurang lengkap dan kurang sistematis sehingga dapat disampaikan bahwa sebagaian besar RPP tersebut kurang layak.

Rencana Pelaksanaan Pembelajaran (RPP) adalah perencanaan pembelajaran yang disusun oleh seorang guru untuk memberikan kemudahan dalam mengajar. Di dalam RPP memuat prosedur dan langkah-langkah pembelajar. Langkah-langkah tersebut meliputi tiga tahap kegiatan, pendahuluan, inti, dan penutup. Rencana tersebut harus menyeluruh dan meliputi semua komponen yang diperlukan selama proses pembelajaran di kelas. Rancangan metoda dan strategi yang digunakan dan alokasi waktu harus sesuai dengan materi dan silabus yang telah ditetapkan sebelumnya. Menurut Sudjana (2013) perencanaan pembelajaran adalah rancangan kegiatan guru dalam melaksanakan pembelajaran. Perencanaan pembelajaran merupakan kegiatan yang akan dilaksanakan oleh seorang guru pada proses pembelajaran di kelas. RPP menjadi barometer terhadap keberhasilan guru dalam melaksanakan pembelajaran agar peserta didik dapat menguasai kompetensi-kompetensi yang berkaitan dengan penguasaan kompetensi sikap, pengetahuan, dan keterampilan.

Sanjaya (2008) menjelaskan bahwa RPP merupakan program perencanaan yang disusun guru sebagai pedoman proses pelaksanaan pembelajaran. RPP yang dirancang guru harus mengikuti aturan-aturan yang ditetapkan oleh pemerintah sehinggah langkah-langkah pembelajaran yang tersusun secara sistematis dengan komponen-komponen yang ditetapkan. 
Kompetensi guru adalah kemampuan yang dimiliki guru dalam menjalankan tugas-tugas pokoknya dalam mengajar dan mendidik di sekolah. Abdul Majid (2005) menjelaskan kompetensi yang dimiliki oleh setiap guru akan menunjukkan kualitas guru dalam mengajar. Kompetensi tersebut akan terwujud dalam bentuk penguasaan pengetahuan dan profesional dalam menjalankan fungsinya sebagai guru. Kompetensi pedagogik menurut Undang-undang No.14 tahun 2005 tentang Guru dan Dosen pasal 10 ayat (1) kompetensi guru meliputi kompetensi pedagogik, kompetensi kepribadian, kompetensi sosial, dan kompetensi profesional yang diperoleh melalui pendidikan profesi.

Untuk mengatasi permasalahan guru yaitu rendahnya kompetensi guru dalam menyusun RPP, Kepala Sekolah dapat mengadakan supervisi akademik yang terencana dengan baik, dijadwalkan waktu pelaksanaannya, dilaksanakan dengan baik, dan ditindaklanjuti dengan baik pula. Kepala sekolah menyatakan bahwa dalam menjalankan tugasnya berpedoman pada program sekolah yang dikenal sebagai program kerja tahunan (RKT). Dalam program kerja tahunan tercantum kegiatan supervisi, salah satunya adalah supervisi akademik disusun oleh kapala sekolah bersama dengan dewan guru.

Berdasarkan asumsi penyebab masalah tersebut diatas penulis berkeinginan melakukan perubahan atau perbaikan dalam hal pembimbingan menyusun rencana pelaksanaan pembelajaran di SMPN 1 Kecamatan Harau dengan cara melaksanakan Penelitian Tindakan Sekolah melalui workshop. Tindakan ini dipilih karena penulis berasumsi bahwa dengan workshop guru dapat belajar bersama melalui diskusi atau tukar pendapat. Selain itu juga guru diharapkan lebih leluasa bekerja karena sudah difasilitasi oleh sekolah.

Workshop adalah pelatihan yang dilaksanakan sekolah dalam rangka meningkatkan kompetensi pendidik dan tenaga kependidikan. Melalui workshop diharapkan tujuan yang dirancang dapat tercapai dengan baik. Menurut Berita Bimtek (2016) workshop adalah latihan dimana peserta bekerja secara individu maupun secara kelompok untuk menyelesaikan pekerjaan yang berkaitan dengan tugas yang sebenarnya untuk mendapatkan pengalaman.

Permasalahan dalam penelitian ini dibatasi dengan peningkatan kompetensi guru dalam menyusun RPP melalui kegiatan workshop di SMPN 1 Kecamatan Harau.

Berdasarkan identifikasi diatas, maka permasalahan penelitian ini dapat dirumuskan sebagai berikut: "Apakah melalui kegiatan workshop dapat meningkatkan kompetensi guru dalam menyusun program pelaksanaan pembelajaran (RPP) di SMPN 1 Kecamatan Harau?

Penelitian ini bertujuan untuk mengetahui peningkatan kemampuan guru dalam menyusun Rencana Pelaksanaan Pembelajaran (RPP) melaui kegiatan workshop di SMPN 1 Kecamatan Harau.

Penelitian ini diharapkan bermanfaat untuk:

1. Meningkatkan kemampuan professional guru.

2. Meningkatkan kemampuan professional Kepala Sekolah.

3. Sebagai pedoman pengambil keputusan bagi pengambil kebijakan.

\section{METODOLOGI}

Dalam penelitian ini adalah Penelitian Tindakan Sekolah (PTS). PTS merupakan suatu penelitian yang dilaksanakan oleh seorang Kepala Sekolah 
dalam rangka untuk meningkatkan atau memperbaiki permasalahan yang ditemukan di sekolah. Permaslahan dapat dilihat dari tugas pokok kepala sekolah, supervisi, manajerial, dan kewirausahaan. Menurut Waitlem dan Risman (2017) Penelitian Tindakan Sekolah merupakan penelitian yang dilaksanakan oleh seorang Kepala Sekolah dengan tujuan meningkatkan kinerja sistem pendidikan dan mengembangkan manajemen sekolah supaya produktif, efektif, dan efisien.

Penelitian dilaksanakan di SMPN 1 Kecamatan Harau Kabupaten Lima Puluh Kota. SMPN 1 Kecamatan harau terletak di pusat ibu kota kabupaten yaitu di kenagarian Koto Tuo Kecamatan Harau.

Subyek penelitian ini adalah guru-guru SMPN 1 Kecamatan Harau yang memperoleh penilaian rendah pada penilaian RPP yang peneliti lakukan sebagai nilai pra-siklus untuk penelitian ini. Ada 22 orang guru yang terlibat pada penelitian ini, nama dan mata pelajaran yang diampu dapat dilihat pada lampiran penelitian. Penelitian ini dilaksanakan pada semester 1 tahun pelajaran 2018/2019.

Penelitian ini dilaksanakan dalam dua siklus, siklus I dan siklus I. Masing-masing siklus terdiri dari tiga pertemuan. Prosedur yang digunakan untuk pengumpulan data adalah sebagai berikut:

\section{Siklus I}

\section{a. Perencanaan tindakan}

Peneliti pertama sekali menginformasikan kepada guru bahwa akan diadakan penelitian tindakan sekolah. Kemudian, peneliti mempersiapkan instrumen penelitian, menginformasikan kepada guru jadwal dan tanggal pelaksanaan tindakan, mempersiapkan nara sumber yang akan memberikan paparan tentang penyusunan RPP.

\section{b.Pelaksanaan Tindakan}

Tindakan yang diberikan kepada guru adalah pelatihan tentang penyusunan RPP untuk guru mata pelajaran. Ada 3 pertemuan pelaksanaan tindakan pada siklus I ini. Pada pertemuan 1, kegiatan yang dilaksanakan adalah pemaparan materi tentang penyusunan RPP oleh narasumber. Semua guru yang menjadi subyek penelitian hadir pada ruangan yang telah ditentukan. Pelaksanaan tindakan ini pada sore hari setelah proses belajar mengajar selesai. Jadi kegiatan tindakan sekolah ini tidak mengganggu PBM.

Pada pertemuan 2 dan 3, guru diminta menyusun RPP yang akan diajarkan di kelas masing-masing. RPP dirancang sesuai dengan KD yang akan diajarkan.

\section{c. Observasi (Pengamatan)}

Pengamatan dilakukan untuk melihat apakah RPP yang disusun guru telah sesuai dengan kaidah penulisan RPP yang tercantum di dalam Standar Proses. Peneliti menggunakan format Penilaian RPP yang telah peneliti siapkan pada tahap perencanaan.

\section{d. Refleksi}

Refleksi dilaksanakan setelah kegiatan siklus I selesai dilaksanakan. Masing-masing RPP yang telah disusun guru telah dinilai dengan menggunakan format penilaian RPP. Maka refleksi digunakan untuk memperbaiki kualitas tindakan maupun pengamatan untuk dijadikan sebagai bahan perbaikan untuk siklus ke 2 . 


\section{Siklus II}

\section{a. Perencanaan tindakan}

Perencanaan tindakan pada siklus II, peneliti berpedoman pada temuan-temuan yang terjadi pada siklus I. Dari temuan tersebut, peneliti koordinasikan ke guru-guru agar lebih serius dan semangat dalam menyusun RPP pada siklus II. Peneliti juga mempersiapkan instrumen penelitian berupa format penilaian RPP dan menentukan jadwal dan tanggal pelaksanaan tindakan pada siklus II,

\section{b. Pelaksanaan Tindakan}

Pada pertemuan 1 siklus II, peneliti memberikan evaluasi pada RPP yang telah disusun guru pada siklus I. evaluasi ini berguna untuk masukan bagi guru terhadap kelemahan-kelemahan RPP yang telah disusun. Dengan demikian guru akan memperbaiki kelemahan-kelemahan pada RPP yang telah dirancangnya dan melanjutkan menyusun RPP yang baru berdasarkan materi yang akan diajarkan pada pertemuan 2 dan 3 siklus II.

\section{c. Observasi}

Pelaksanaan observasi sama dengan yang dilakukan pada siklus I. Peneliti menilai RPP yang telah disusun guru dengan menggunakan format penilaian RPP yang telah dipersiapkan sebelum penelitian.

\section{d. Refleksi}

Refleksi dilaksanakan setelah kegiatan siklus II selesai dilaksanakan. Refleksi digunakan untuk menetukan apakah penelitian selesai atau berlanjut ke siklus berikutnya.

Instrumen yang digunakan untuk menilai RPP yang disusun guru adalah Instrumen Penilaian Rencana Pelaksanaan Pembelajaran (RPP). Data dianalisis dengan menggunakan persentase. Disini peneliti mengelompokkan kompetensi guru berdasarkan empat kategori, yaitu perolehan nilai anatara $90 \leq \mathrm{A} \leq 100$ adalah Amat Baik (AB), $75 \leq \mathrm{B}<90$ adalah Baik (B), $60 \leq \mathrm{C}<74$ adalah Cukup (C), dan $<60$ adalah Kurang (K). Tindakan dalam penelitian ini dianggap berhasil apabila guru mampu menyusun RPP dengan mencapai nilai minimal Baik.

\section{TEMUAN DAN PEMBAHASAN}

\section{Prasiklus}

Nilai prasiklus diambil dari nilai supervisi perangkat pada semester II tahun pembelajaran 2017/2018. Berdasarkan temuan nilai guru menyusun RPP pada supervisi semester II tahun pelajaran 2017/2018 di atas, maka peneliti sebagai kepala sekolah tertantang untuk melaksanakan sebuah tindakan. Tindakan ini bertujuan agar para guru di SMPN 1 Kecamatan Harau mampu menyusun RPP sendiri, tidak lagi melakukan tindakan meniru RPP guru lain.

Dari temuan prasiklus, dapat dijabarkan bahwa kemampuan guru menyusun RPP adalah dengan nilai rata-rata 65,10 dengan kategori Cukup. Ada sepuluh komponen yang dinilai dalam penyususnan RPP, baru dua komponen yang bernilai dengan kategori Baik, yaitu komponen Identitas Mata Pelajaran dan Pemilihan Kompetensi dengan nilai rata-rata 75,76 dan 76, 52 kategori Baik. 
Dari permasalah tersebut, peneliti melasanakan workshop penyusunan RPP dengan mendatangkan seorang Pengawas Pendidikan yaitunya Bpk. Jontar Nababan.

\section{Siklus I}

Pelaksanaan Siklus I pertemuan 1 pada hari Sabtu 4 Agustus 2018, pukul 14.00 s.d 17.30 wib. workshop dilaksanakan tentang penyusunan Rencana Pelaksanaan Pembelajaran (RPP) untuk semua mata pelajaran. Kegiatan penelitian tindakan pada siklus I adalah sebagai berikut:

\section{a. Perencanaan}

Pada tahap perencanaan, peneliti melaksanakan kegiatan sebagai berikut:

1) Menghubungi nara sumber yaitu salah seorang pengawas sekolah yang berkompeten tentang penyusunan RPP

2) Menyediakan format rencana pelaksanaan pembelajaran (format RPP)

3) Menyiapkan contoh rencana pelaksanaan pembelajaran

4) Menyusun instrumen penilaian rencana pelaksanaan pembelajaran

\section{b. Pelaksanaan}

Dalam tahapan kegiatan pelaksanaan yang dilakukan pada siklus I adalah sebagai berikut:

1) Pertemuan 1

Pertemuan 1 dilaksanakan pada hari Sabtu tanggal Sabtu tanggal 4 Agustus 2018. kegiatan pelatihan diadakan di luar sekolah. Kegiatan dilaksanakan di Bio Homestay Harau. Guru diinapkan selama 2 hari, Sabtu dan minggu dengan kegitan sebagai berikut:

a) Pembukaan pelaksanaan workshop tentang penyusunan RPP oleh kepala sekolah.

b) Penyampaian materi (pembekalan) tentang bagaimana cara penyusunan rencana pelaksanaan pembelajaran yang baik dan benar oleh nara Sumber. Nara sumber adalah seorang pengawas sekolah.

c) Memberi kesempatan kepada peserta untuk menanyakan hal-hal yang belum jelas pada penyampaian materi tentang RPP

d) Memberikan waktu untuk peserta untuk memberikan tanggapan saran-saran yang berkenaan dengan penyampaian materi yang disampaikan.

2) Pertemuan 2, dilaksanakan latihan menyusun RPP pada hari Minggu tanggal 5 Agustus 2018 dari pukul 08.00 s.d 12.30 wib. Pada pertemuan 2 ini, peneliti meminta guru untuk membuat RPP sesuai dengan kaidah-kaidah yang disampaikan oleh nara sumber pada pertemuan 1. Guru bebas bekerja secara individu maupun berkelompok.

3) Pertemuan 3, dilaksanakan pada hari Sabtu tanggal 25 Agustus. Pertemuan 3 ini dilaksanakan di sekolah. Kegiatan dimulai pukul 14.00 s.d 16.00. Adapun kegiatan pada pertemuan ini adalah melanjutkan penyusunan RPP seperti pada pertemuan 2. Peneliti mendampingi peserta workshop selama penelitian tindakan sekolah ini berlangsung. 


\section{c. Observasi}

Pada Tahap observasi, di sini peneliti melaksanakan observasi dokumen, yaitu peneliti melakukan penilaian terhadap dokumen RPP yang telah disusun oleh guru selama pelaksanaan penelitian tindakan sekolah Siklus I. Penelitin melakukan telaah RPP dengan menggunakan format telaah RPP yang telah dipersiapkan pada tahap perencanaan penelitian tindakan sekolah. Setelah pelaksanaan Tindakan pada siklus I diperoleh hasil sebagai berikut: rata-rata nilai kemampuan guru menyusun RPP melalui pelaksanaan workshop adalah 75,22\% artinya memperoleh prediket B. Masih ada lima komponen RPP lagi yang memperoleh nilai Cukup.

Selanjutnya, ditinjau dari jumlah peserta yang telah memperoleh nilai baik adalah sembilan orang dari dua puluh dua subyek penelitian. Dengan demikian, guru yang memperoleh nilai baik baru mencapai $40,91 \%$. Jadi masih ada tiga belas guru lagi yang perlu ditingkatkan kemampuannya dalam menyusun RPP.

\section{d. Refleksi}

Temuan pada siklus I menunjukkan bahwa sudah terjadi peningkatan kemampuan guru dalam menyusun RPP di SMPN 1 Kec. Harau pada semester 1 tahun pelajaran 2018/2019. tetapi walaupan sudah diperoleh peningkatan namun masih ada tiga belas guru lagi yang perlu ditingkatkan kemampuannya dalam menyusun RPP. Oleh sebab itu, penelitian tindakan sekolah ini berlanjut ke siklus II dengan memperhatikan titik lemah kemampuan guru menyusun RPP terutama pada guru yang masih memperoleh nilai $\mathrm{C}$.

\section{Siklus II}

Siklus II dilaksanakan pada hari Sabtu, 15 September 2018. penelitian dimulai pukul 11.00 s.d. 12.30 wib. Kegiatan yang dilaksanakan adalah penyusunan Rencana Pelaksanaan Pembelajaran (RPP) untuk semua guru yang terpilih sebagai subyek kegiatan penelitian tindakan sekolah ini. Kegiatan pada siklus 2 ini adalah sebagai berikut:

\section{a. Persiapan}

Pada tahapan persiapan yang dilakukan pada siklus 2 adalah sebagai berikut :

1) menentukan jadwal pelaksanaan penelitian tindakan sekolah dengan guru yang terpilih sebagai subyek penelitian.

2) Menyediakan format rencana pelaksanaan pembelajaran (Format RPP).

3) Menyiapkan contoh rencana pelaksanaan pembelajaran pembelajaran yang sesuai dengan Standar Proses.

4) Mendatangkan pengawas sekolah untuk mengamati pelaksanaan pelatihan (workshop) penyusunan RPP

5) Menyiapkan instrumen penilaian rencana pelaksanaan pembelajaran

\section{b. Pelaksanaan}

Pada kegiatan pelaksanaan siklus II adalah sebagai berikut :

1) Pertemuan 1

Kegiatan pertemuan 1 siklus 2 adalah pada hari Sabtu tanggal 15 September 2018. penelitian dimulai pukul 11.00 s.d. 12.30 wib. Adapun kegiatan yang dilaksanakan adalah sebagai berikut: 
a) Guru mengumpulkan hasil pekerjaan kepada fasilitator (kepala sekolah).

b) Kepala Sekolah, meminta perwakilan dari salah satu guru untuk mempresentasikan hasil kerjanya.

c) Peserta yang lainnya membahas hasil paparan yang disampaikan, kemudian memberikan tanggapan berupa saran untuk perbaikan hasil kerja guru.

d) Kemudian peserta lain mendapatkan giliran mempresentasikan hasil kerjanya demi perbaikan RPP yang telah disusun.

2) Pertemuan 2

Pertemuan 2 pada siklus II dilaksanakan pada hari Sabtu tanggal 22 September 2018. kegiatan yang dilakukan guru adalah meyusun RPP baru berdasarkan materi yang akan diajarkan guru pada minggu berikutnya. Oleh sebab itu, RPP yang dirancang guru dapat diaplikasikan di dalam proses pembelajaran di kelas. Peneliti selaku kepala sekolah memberikan bimbingan langsung pada kegiatan ini.

Selanjutnya, guru melanjutkan penyusunan RPP bagi yang belum selesai di rumah untuk dikumpulkan kepada kepala sekolah untuk dinilai dengan menggunakan telaah RPP

3) Pertemuan 3

Pada pertemuan 3, peneliti melaksanakan penilaian terhadap RPP yang telah disusun guru. Pada saat ini, peneliti bekerja menilai RPP guru dengan menggunakan format penilaian RPP.

\section{c. Observasi}

Dari hasil observasi melalui observasi dokumen RPP yang disusun guru pada siklus II, hasil telaah RPP siklus II diperoleh temuan bahwa rata-rata nilai kemampuan menyusun RPP guru melalui workshop adalah 89,29\% dengan Peringkat B. Semua komponen RPP berhasil diselesaikan dengan baik oleh seluruh peserta workshop yang menjadi subyek penelitian tindakan sekolah ini. Temuan menunjkan bahwa ada empat oarng guru yang memperoleh nilai dengan peringkat A dan selebihnya dengan peringkat B yaitu delapan belas orang guru.

\section{d. Refleksi}

Setelah selesai tahap pelaksanaan dan observasi pada siklus II ini, maka peneliti merenungkan perolehan tersebut. Perenungan dimulai dari pelaksanaan, dari tiga pertemuan pada siklus II ini telah terlaksana dengan baik. Kemudian refleksi dilanjutkan dengan memperhatikan nilai perolehan dari telaah RPP yang disusun guru. Dari hasil telah RPP maka diperoleh bahwa semua guru telah memperoleh nilai dengan peringkat minimal Baik. Dimana dapat dirinci bahw ada empat orang guru yang memperoleh nilai dengan peringkat Amat Baik (A) dan delapan belas orang guru dengan peringkat Baik (B). berdasarkan temuan tersebut, maka penelitian tindakan sekolah ini dihentikan karena indikator keberhasilan penelitian sudah tercapai yaitu apabila guru mampu menyusun RPP dengan mencapai nilai minimal Baik. 


\section{A. Pembahasan}

\section{Peningkatan dari Prasiklus - Siklus I}

Berdasarkan temuan penelitian tindakan sekolah tentang "Peningkatan Kemampuan Guru Dalam Menyusun Rencana Pelaksanaan Pembelajaran (RPP) melalui Workshop di SMPN 1 Kecamatan Harau" dapat dijelaskan terjadi peningkatan dari nilai prasiklus ke temuan pada siklus I. Temuan penelitian pada siklus I dapat dilihat terjadi peningkatan dari nilai kemampuan guru menyusun RPP pada Prasiklus. Perolehan nilai rata-rata kemampuan gur pada prasiklus adalah $65,10 \%$, kemudian setelah mengikuti workshop tentang penyusunan RPP pada siklus I maka nilai perolehan guru dalam menyusun RPP meningkat menjadi 75,22\%. Terjadi peningkatan sebesar $10,12 \%$. Selanjutnya peningkatan nilai kemampuan guru menyusun RPP di SMPN 1 Kecamatan Harau melalui workshop dapat dilihat pada grafik di bawah ini:

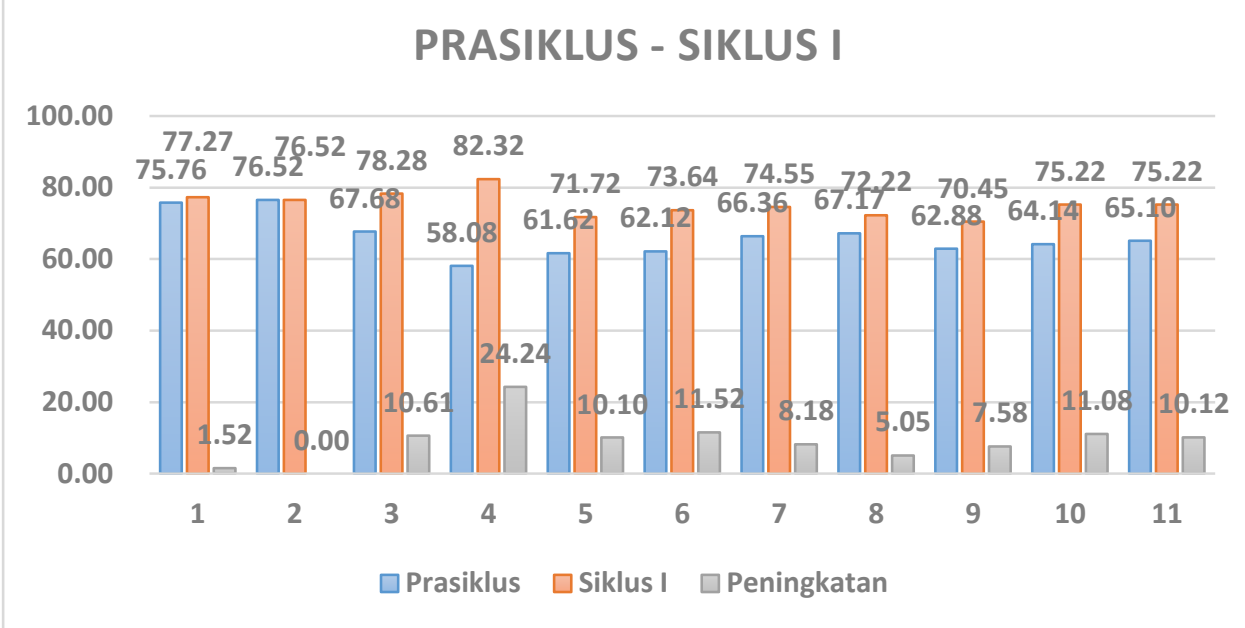

Grafik 1: Peningkatan Penilaian Rencana Pelaksanaan Pembelajaran (RPP) SMPN 1 Kecamatan Harau (Prasiklus-Siklus I)

2. Peningkatan dari Siklus I - Siklus II

Peningkatan nilai guru dalam penyusunan RPP dari siklus I ke Siklus II adalah sebesar $14,07 \%$. peningkatan ini diperoleh dari nilai guru pada Siklus I sebesar $75,22 \%$ dan meningkat menjdi $89,29 \%$ pada Siklus II. Peningkatan ini juga dapat dilihat pada grafik 2 di bawah ini:

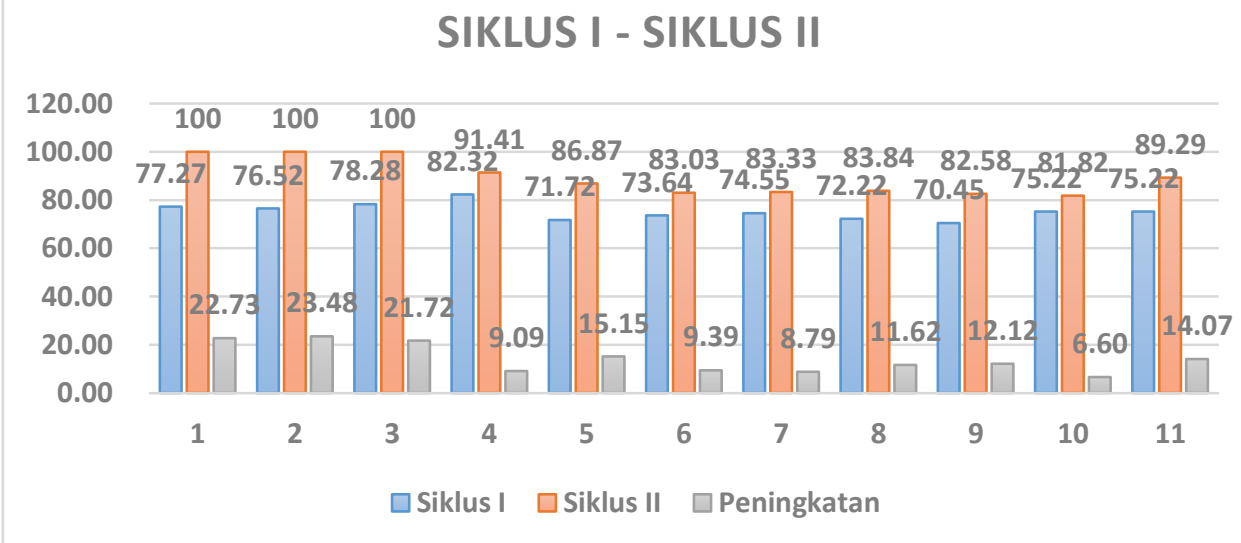

Grafik 1: Peningkatan Penilaian Rencana Pelaksanaan Pembelajaran (RPP) SMPN 1 Kecamatan Harau (Siklus I-Siklus II) 
Berdasarkan temuan penelitian tindakan sekolah tentang "Peningkatan Kemampuan Guru Menyusun Rencana Pelaksanaan Pembelajaran (RPP) melalui Workshop di SMPN 1 Kecamatan Harau maka dapat dijelaskan bahwa workshop sangat bermanfaat dalam melatih guru tentang penyususnan RPP. Dari temuan terlihat peningkatan yang nyata kemampuan guru dalam menyususn RPP. Hal ini terlihat peningkatan nilai perolehan dari Prasiklus ke siklus I dan Siklus II.

\section{KESIMPULAN DAN SARAN}

Berdasarkan hasil pelaksanaan workshop penyusunan RPP di SMPN 1 Kecamatan Harau Kabupaten Lima Puluh Kota, Sumatra Barat, dalam upaya meningkatkan kemampuan guru menyusun Rencana Pelaksaan Pembelajaran (RPP) dapat disimpulkan sebagai berikut :

Penggunaan workshop dalam upaya meningkatkan kemampuan guru menyusun rencana pelaksanaan pembelajaran di SMPN 1 Kecamatan Harau Kabupaten Lima Puluh Kota, adalah baik sekali. Ini terbukti terjadi peningkatan kemampuan guru dari prasiklus ke siklus I sebesar $10,12 \%$ dan dari siklus I ke Siklus II sebesar 14,07\%

Berdasarkan temuan penelitian ini, peneliti ingin menyarankan kepada:

1. Kepala Sekolah agar senatiasa mengembangkan potensi diri dan berusaha untuk memberikan yang terbaik terhadap guru yang dipimpinnya.

2. Guru sebaiknya selalu meningkatkan kompetensi yang dimiliki terutama dalam menjalankan tugas pokok seorang guru supaya hasil pendidikan juga meningkat.

3. Pengawas sekolah diharapkan membimbing kepala sekolah dan guru dalam melaksanakan tugas-tugas supaya tujuan pendidikan terlaksana dengan baik.

\section{DAFTAR PUSTAKA}

Abdul Majid. (2005). Perencanaan Pembelajaran Mengembangkan Standar Kompetensi Guru. Bandung: Remaja Rosdakarya

Berita Bimtek. 2016. Definisi Seminar, Lokakarya, workshop, Bimbingan Teknis, Pendidikan dan Pelatihan, dan Sosialisasi. https://beritabimtek.wordpress.com/2016/07/07/definisi-seminar-lokakar ya-workshop-bimbingan-teknis-pendidikan-dan-pelatihan-dan-sosialisasi

Depdiknas. (2005). Peraturan Pemerintah RI No.19 Tahun 2005 tentang Standar Nasional Pendidikan. Jakarta: Depdiknas.

Departemen Pendidikan Nasional. 2005. Undang-Undang Republik Indonesia, Nomor 14 Tahun 2005 Tentang Guru dan Dosen. Depdiknas RI : Jakarta

Kunandar. 2011. Guru Profesional (Implementasi Kurikulum Tingkat Satuan Pendidikan dan Sukses dalam Sertifikasi Guru). Jakarta: Raja Grafindo Persada

Permendikbud no 22 tahun 2016 tentang Standart proses Sekolah Dasar dan Menengah. Jakarta: Kementrian Pendidikan dan Kebudayaan

Permendikbud Nomor 22 Tahun 2016 Tentang Standar Proses. Pendidikan Dan Menengah. Jakarta: Kemendikbud. 
Permennegpan RB. 2009. Peraturan Menteri Negara Pendayagunaan Aparatur Negara dan Reformasi Birokrasi Nomor 16 Tahun 2009 tentang Jabatan Fungsional Guru dan Angka Kreditnya. Jakarta

Sanjaya, Wina. 2008. Strategi Pembelajaran Berorientasi Standar Proses Pendidikan. Jakarta: Kencana Prenada Media Group.

Sudjana, Nana. 2013. Dasar-Dasar Proses Belajar Mengajar. (Bandung: Sinar Baru Algesindo)

Waitlem dan Risman. 2017. Praktik Praktis Penulisan Karya Tulis Ilmiah untuk Guru. Padang. CV, Visigraf 